\title{
Hard reason and deep humanity
}

J. W. S. Pringle

Insects and the Life of Man: Collected Essays on Pure Science and Applied Biology. By Sir Vincent Wigglesworth. Pp. 217. (London: Chapman and Hall, 1976. Distributed in the USA by Halsted Press, a Division of Wiley: New York.) Paperback £3.25; hardback $£ 6$.

THIs book is a collection of essays or addresses published over a period of nearly forty years. Many of them are concerned with aspects of applied entomology and its relation to 'pure' science, but the life of man means more than just his material needs. So it is appropriate that the volume includes some of the contributions which Professor Wigglesworth has made to the history and philosophy of science and. in the widest sense, to its art.

The introductory chapter gives a guide to what follows. The earliest contribution is an article published in 1935 on malaria in Ceylon, which may well have stimuated the successful WHO campaign after the war. Wigglesworth did not foresee the problems that would arise from the resulting population explosion, but he did clearly forecast in 1945 the ecological effects that would result from widespread use of DDT. By 1951 he was acknowledging that "there can be no immediate prospect of abandoning the use of insecticides" hut was pleading for more knowledge, with which "we should be able to devise methods of cultivation which would favour the crop and discourage the insect pest to the point where a satisfactory balance is established". 'This was well before the invention of "integrated control".

The essays are not primarily autobiographical, but chapter 12-an address to XIIth International Congress of Entomology in 1964-does start with a brief summary of Wigglesworth's career. Few people know that the Rhodnius cultures now so widespread in biological laboratories derive from a small stock imported from Venezuela about 1924 and laboratory-bred ever since. There follows a review of fifty years' progress in many fields of insect physiology since 1912-“"impressive examples of the potential contribution of insect physiology to general biology". Yet, "I believe that the great era of insect physiology is yet to come": with the fertile observation that meta- morphosis is a genetic switch, a step-wise activation of particular components of the genetic code, and that because in insects the switch is controlled by a single chemical, the juvenile hormone, "there is no more promising medium than the insect, in which this problem can hopefully be studied".

There is a stimulating essay (given to the British Association in 1948) on the history of entomological studies in Britain and the relationship between applied entomology and research. I particularly like the remarks about administration: "The keynote [of administration] should be the safeguarding and encouragement of research. Anyone who has tried both knows that administration is so immeasurably easier than research that it becomes the line of least resistance, and that is why research needs encouragement". Entirely historical is a sketch of the contributions of Sir John Lubbock (Lord Avebury) to insect physiology, "to put the record straight". "If Lubbock had held an academic appointment. he would have been accorded a high place among the biologists of the nineteenth century. But, like Darwin, he was an amateur; and unlike Darwin, he devoted only a minute fraction of his time to scientific pursuits".

Chapter 13 reprints a remarkable article on the epidermal cell, which is often overlooked since it was published in a Festschrift after delivery as a lecture to the Royal Society. The diversity of functions which these cells can perform is one of the most remarkable phenomena in the whole of biology. There is material here for a generation of PhD theses.

The man behind the words comes through most clearly in chapter 16 (Wordsworth and Science) and in chapters 4 and 17 (Science, Pure and Applied; The Religion of Science). He admires Wordsworth "who, standing at the threshold of the Industrial Revolution . . can compare with true scientific objectivity, though with all a poet's feeling, the evil of the factory child with the grinding penury of rural England" and who can, in 1810, find a solution and a hope in "a System of National Education established universally by Government". In chapters 4 and 17, Wigglesworth sets out clearly his faith, on which science is founded and by which it lives. "Without a deeply rooted instinctive belief in the existence of laws which reign throughout nature. the incredible labours of scientists would be without hope". Some rude things are said about philosophers, but the lecture was "anti-philosophical only to the extent that it takes the view that science and idealist philosophy have different ground rules and therefore cannot play together". The picture is of a man of hard reason, coupled with deep humanity.

I have only sampled some of the gems in this book.

J. W. S. Pringle is Linacre Professor of Zoology at the University of Oxford. UK.

\section{Epidemics and pestilences}

Insects and History. (The World Naturalist Series.) By J. L. CloudsleyThompson. Pp. $x+242$. (Weidenfeld and Nicolson: London, 1976.) $£ 8.50$.

THIS is a history book about pestilences, from the dawn of history to the present day. It is vividly written and well documented. Much of it makes horrifying reading. As the story progresses it seems to support the popular view that great epidemics are a thing of the past. But that past is not so very distant: the influenza pandemic of 1918 is thought to have resulted in 20 million deaths-a larger number than any other pestilence in history. The chapter headings read like an account of medical entomology. But the value and interest of the book is enhanced by the large amount of space given to smallpox, scurvy, syphilis, famine and, of course, to the mixed infections and unidentified diseases which defy diagnosis at this distance in time.

The author is cautious in his attributions of historic change to specific insect-borne diseases. The well known idea of W. H. S. Jones that the loss of vigour among the Greeks when the power of Rome was increasing, was the 